\title{
Determination of DNA Methylation Levels with CRED-RA Technique in the Genome of Sunflower Seedlings (Helianthus annuus L.) Subjected to Zinc Stress
}

\author{
E. Bolukbasi, E. S. Aras \\ Department of Biology,Faculty of Science, Ankara University, Ankara, Turkey
}

\begin{abstract}
Heavy metal pollution is a major environmental problem all over the world. It is known that high concentration of heavy metals in soils and waters cause genotoxicity and damage to most of the functional biomolecules. This event is a potentially dangerous for every living organism from plants to humans. The aim of this study was to determine the methylcytosine levels in sunflower (Helianthus annuus L.) genome and changes in methylation patterns under heavy metal of zinc stress. Sunflower seeds were treated with different concentrations of zinc $(0,20,40,80,160,320,640$, $1280 \mathrm{ppm}$ ) for 3 weeks. The overview of the seedlings showed that the growth and development of seedlings were inhibited by 80ppm and following the increase of concentrations. The genomic DNA was extracted 3 weeks after zinc treatments. DNA band variations were revealed by random amplified polymorphic DNA (RAPD) analysis. And then, levels of methylcytosine in the genome were detected with the technique of coupled restriction enzyme digestion-random amplification (CRED-RA). CRED-RA is a significant technique which uses methylation-sensitive enzymes, HpaII and MspI for determining the methylation patterns. According to the RAPD and CRED-RA analysis, GTS rates adapted with RAPD profiles, when compared, the highest rate was $92.85 \%$ at 20ppm zinc concentration. The lowest rate was $83.33 \%$ at 640ppm zinc. Additionally, total methylation and full-methylation rates decreased until 160ppm zinc stress and then started to increase at $320 p p m$ and more concentrations of zinc stressin comparison to the control groups. Similarly, the maximum percentage of non-methylation was detected $5.7 \%$ at 160 ppm zinc stress. According to results of RAPD and CRED-RA analysis, very important polymorphism and methylation changes were observed in sunflower plants subjected to zinc stress.
\end{abstract}

Keywords - Methylation, CRED-RA, heavy metal, zinc stress, sunflower.

\section{INTRODUCTION}

Crop plants such as sunflower are frequently exposed to a variety of abiotic stresses including drought, salinity and heavy metal pollutions. Heavy metal pollution is one of the important constraint to plants growth and development. Several industrial activities, urban waste, spraying and fertilization held in agriculture and uses of heavy metal-containing pesticides are some of the sources of heavy metal pollution. These pollutants causes decrease in the quality of agricultural products [1, 2]. Heavy metals also cause damage to most of the functional biomolecules including membrane lipids and this results in increase of some reactive oxygen types which cause oxidative stress [3]. This situation occurs as a results of treating organisms with some chemical, biological and physical agents that leads to damages in their genetic materials [4-7].

Zinc is a microelement which should be taken in very less amounts by plants, animals and humans. But the toxic effect of Zinc cause damages to the cell division and it especially gives damages to the cell nucleus in plants. [8, 9]. Additionally, heavy metal stress cause changes in DNA methylation patterns [10].

DNA methylation is one of the important enzymatic modification which occurs the addition of a methyl group into the carbon-5 cytosine and plays a vital role in epigenetic control of gene expression in plants. DNA methylation is hereditary modification which transferred from generation to generation and also reversible process that the methyl group can be removed to come back to the original structure. Because of this features, methylation is an epigenetic mechanism and significance example of epigenetic code. DNA methylation is also considered to contribute to biodefense in plants [11-13].

Levels of methylcytosine in the genome can be detected with many techniques [14, 15]. Coupled restriction enzyme digestion and random amplification (CRED-RA) is significant technique for studying the methylation status in plants. The CRED-RA technique has been 
examined successfully in many studies with different plant species to determine their methylation patterns [16$18]$.

In this study, it was aimed to determine the effect of zinc heavy metal on sunflower (Helianthus annuus L.) seedlings by the use of RAPD analysis for possible genotoxicity, which is one of the PCR-based molecular indicators. Additionally, possible methylation differences between the treatment groups with various zinc solution in comparison to control plants were evaluated.

\section{MATERIALS AND METHODS}

\section{Plant materials, growth conditions and stress}

\section{treatment}

Sunflower (Helianthus annuus L.) seeds' surfaces were sterilized with $70 \%$ alcohol and $30 \%$ sodium hypochlorite solution and washed three-four times with distilled water. For germinating and growing of sunflower seeds, seedling trays were filled with sterile perlite and seeds were planted in each cell of seedling tray. The seedling tray was divided into eight groups in total, including control and seven different concentrations of zinc solution.Control group of the trayswas treated with only $15 \mathrm{~mL}$ of modified 1/10 Hoagland solution. Hoagland solution includes macronutrients $\left(\mathrm{K}_{2} \mathrm{SO}_{4}, \mathrm{KH}_{2} \mathrm{PO}_{4}\right.$, $\left.\mathrm{MgSO}_{4} .7 \mathrm{H}_{2} \mathrm{O}, \quad \mathrm{Ca}\left(\mathrm{NO}_{3}\right)_{2} .4 \mathrm{H}_{2} \mathrm{O}, \quad \mathrm{KCl}\right)$, micronutrients $\left(\mathrm{H}_{3} \mathrm{BO}_{3}, \mathrm{MnSO}_{4}, \mathrm{CuSO}_{4} \cdot 5 \mathrm{H}_{2} \mathrm{O}, \mathrm{NH}_{4} \mathrm{Mo}, \mathrm{ZnSO}_{4} \cdot 7 \mathrm{H}_{2} \mathrm{O}\right)$ and ions in the following concentrations: $2 \mathrm{mM} \mathrm{Ca}, 10^{-6} \mathrm{M}$ $\mathrm{Mn}, 4 \mathrm{mM} \mathrm{NO} 3,2.10^{-7} \mathrm{M} \mathrm{Cu}, 1 \mathrm{mM} \mathrm{Mg}, 10^{-8} \mathrm{M} \mathrm{NH}_{4}$, $2 \mathrm{mM} \mathrm{K}, 10^{-6} \mathrm{M} \mathrm{Zn}, 0.2 \mathrm{mM} \mathrm{P}, 10^{-4} \mathrm{M} \mathrm{Fe}$, and $10^{-6} \mathrm{M} \mathrm{B}$. The other groups of the trays were treated with $15 \mathrm{~mL}$ of $20,40,80,160,320,640,1280 \mathrm{ppm}$ concentrations of Zinc $\left(\mathrm{Zn}^{2+}\right)$ solutions for each, respectively. These treatments were replicated twice. All groups were grown in a controlled environmental growth chamber with light of $250 \mathrm{mmol} \mathrm{m} \mathrm{m}^{-2} \mathrm{~s}^{-1}$ photosynthetic photon flux at $25^{\circ} \mathrm{C}$, $70 \%$ relative humidity. All these procedures were performed for 21 days. After 21days of treatment, the harvested plants were frozen in liquid nitrogen and stored at $-20^{\circ} \mathrm{C}$ until DNA extraction.

\section{Genomic DNA isolation}

The pieces $(200 \mathrm{mg})$ of roots obtained from the seedlings exposed zinc stress was grounded with liquid nitrogen, and total genomic DNA was extracted from sunflower samples. DNA isolation was performed with the DNA isolation protocol of Lefort [19]. The quantity and quality of DNA samples were determined byNanodrop Spectrophotometer (NanoDrop ND-1000 Spectrophotometer, Thermo Scientific) and also confirmed by gel electrophoresis which contains $1.5 \%$ agarose and $0.05 \mu \mathrm{l} / \mathrm{ml}$ ethidium bromide. The amount and purity of DNA samples were given in Table 1.
Table.1: The quantity and quality of DNA samples obtained from sunflower plants subjected to zinc stress

\begin{tabular}{cccc}
\hline Samples & $\mathbf{n g} / \boldsymbol{\mu l}$ & $\mathbf{2 6 0 / 2 8 0}$ & $\mathbf{2 6 0 / 2 3 0}$ \\
\hline Control & 781,2 & 2,00 & 1,62 \\
$20 \mathrm{ppm}$ & 602,2 & 2,02 & 1,59 \\
$40 \mathrm{ppm}$ & 608,9 & 2,05 & 1,51 \\
$80 \mathrm{ppm}$ & 2843,4 & 2,03 & 1,61 \\
$160 \mathrm{ppm}$ & 3465,7 & 2,01 & 1,56 \\
$320 \mathrm{ppm}$ & 927,8 & 2,03 & 1,61 \\
$640 \mathrm{ppm}$ & 1249,7 & 1,99 & 1,68 \\
$1280 \mathrm{ppm}$ & 1151,4 & 2,01 & 1,59 \\
\hline
\end{tabular}

\section{RAPD (Random Amplified Polymorphic DNA) procedure}

For the RAPD reaction, suitable purity and concentration levels of DNA samples were selected. RAPD-PCR study was performed with total $25 \mu \mathrm{l}$ standard reaction volume for each sample. Optimum amplification conditions were obtained with 200ng genomic DNA, 1× reaction buffer, $2.5 \mathrm{mM} \mathrm{MgCl}_{2}, 20 \mu \mathrm{M}$ dNTPs, $0.2 \mathrm{mM}$ primer, and $0,5 \mathrm{U}$ Taq DNA polymerase (Promega), and a PCR mix was prepared with these amounts. 14 of 20 RAPD primers used in this study revealed polymorphic bands that are different from the control group of sunflower. Nucleotide sequences of 14 primerswere used for RAPD-PCR reactions were given Table 2. The thermal cycling conditions included an initial denaturation step of $95^{\circ} \mathrm{C}$ for $5 \mathrm{~min}$, followed by 35 cycles of $94^{\circ} \mathrm{C}$ for $90 \mathrm{~s}$ (denaturation), $36^{\circ} \mathrm{C}$ for $60 \mathrm{~s}$ (annealing), and $72^{\circ} \mathrm{C}$ for 120 s (extension) followed by a final extension period of $72^{\circ} \mathrm{C}$ for $5 \mathrm{~min}$. Negative control PCR, not including any DNA template was run for each of samples for testing any other kinds of contamination. All PCR reactions were carried out in duplicate. PCR reaction products and DNA ladder (DNA ladder plus, Promega 100bp) were exposed to an electrophoretic separation process for 2-2.5h, under $5 \mathrm{~V} / \mathrm{cm}$ current in $1.5 \%$ agarose gel containing $0.05 \mu \mathrm{l} / \mathrm{ml}$ ethidium bromide. The gels were displayed with UV imaging system (Gene Genius, Syngene); and photographed with using (GyneSnap Software, Synoptics Co). After then, gel photographs were analyzed for identifying the RAPD profiles.

After analysis of the RAPD profiles, genomic template stability (\%) was calculated with the following formula: GTS $=(1-\mathrm{a} / \mathrm{n}) \times 100$, where letter of a;refers to polymorphic band number of each sample, which was treated with the different zinc solutions and letter of $\mathrm{n}$; refers to the total band number in the control. The appearance or disappearance of bands in the treated sample' RAPD profiles in comparison to the control RAPD profiles were identified as polymorphism. 
Table.2: Nucleotide sequences of primers were used for $R A P D-P C R$ reactions

\begin{tabular}{lc}
\hline \multicolumn{1}{c}{ Primers } & Nucleotide sequence $\left(\mathbf{5}^{\prime} \rightarrow \mathbf{3}^{\prime}\right)$ \\
\hline OPC-01* & TTCGAGCCAG \\
\hline OPC-02* & GTGAGGCGTC \\
OPC-04* & CCGCATCTAC \\
OPC-05* & TGGACCGGTG \\
OPC-06* & GAACGGACTC \\
OPC-07 & GTCCCGACGA \\
OPC-08* & TGGACCGGTG \\
OPC-09 & CTCACCGTCC \\
OPC-10 & TGTCTGGGTG \\
OPC-11* & AAAGCTGCGG \\
OPA-03* & AGTCAGCCAC \\
OPA-08 & GTGACGTAGG \\
OPB-07 & GGTGACGCAG \\
OPF-05 & CCGAATTCCC \\
\hline refer to primers which used for CRED-RA analysis
\end{tabular}

CRED-RA (Coupled restriction enzyme digestion and random amplification) assay

Digestion of genomic DNA with the restriction enzymes

To observe the differences in methylation patterns of the genomic DNA between the control and treated groups, MspI and HpaII enzymes were used. CRED-RA study was performed with total $20 \mu \mathrm{l}$ standard reaction volume for each sample. In $20 \mu 1$ reaction volume, approximately $1 \mu \mathrm{g}$ of genomic DNA, $2 \mu \mathrm{l} 10 \mathrm{X}$ of enzyme reaction buffer and $10 \mathrm{U}$ of restriction enzyme were used. The microcentrifuge tubes containing the components given above were held in water-bath with the temperature of $37^{\circ} \mathrm{C}$ for 4 hours. At the end of this incubation, the samples were held in the heat-block with the temperature of $95^{\circ} \mathrm{C}$ for 15 minutes for the inactivation of restriction enzymes.

\section{PCR components and conditions}

In $25 \mu \mathrm{l}$ reaction volume, approximately 200ng of digestion product, $2.5 \mu \mathrm{l} 10 \mathrm{X}$ of reaction buffer, $20 \mathrm{mM}$ dNTPs, $2.5 \mu \mathrm{MgCl}_{2}, 0.2 \mathrm{mM}$ for each primer, $0.5 \mathrm{U}$ Taq DNA polymerase were used. 8 of 14 RAPD primers (OPC01, OPC02, OPC04, OPC05, OPC06, OPC08, OPC011 and OPA03) that showed monomorphic band profiles in RAPD-PCR were used in the CRED-RA analysis. Agarose gel images of 8 primers that showed monomorphic band profilesin RAPD-PCR analysis were given in Figure 1. Optimized PCR reactionswere performed an initial denaturation step of $96^{\circ} \mathrm{C}$ for $90 \mathrm{~s}$, followed by 45 cycles of $95^{\circ} \mathrm{C}$ for 30 s (denaturation), $36^{\circ} \mathrm{C}$ for 60 s (annealing), and $72^{\circ} \mathrm{C}$ for 120 s (extension) followed by a final extension period of $72^{\circ} \mathrm{C}$ for $10 \mathrm{~min}$. Amplified samples were loaded into $1.6 \%$ of agarose gel; they were run electrophoretically at $5 \mathrm{~V} / \mathrm{cm}$ for 3 hours. Negative control was used for testing any other kinds of contamination.

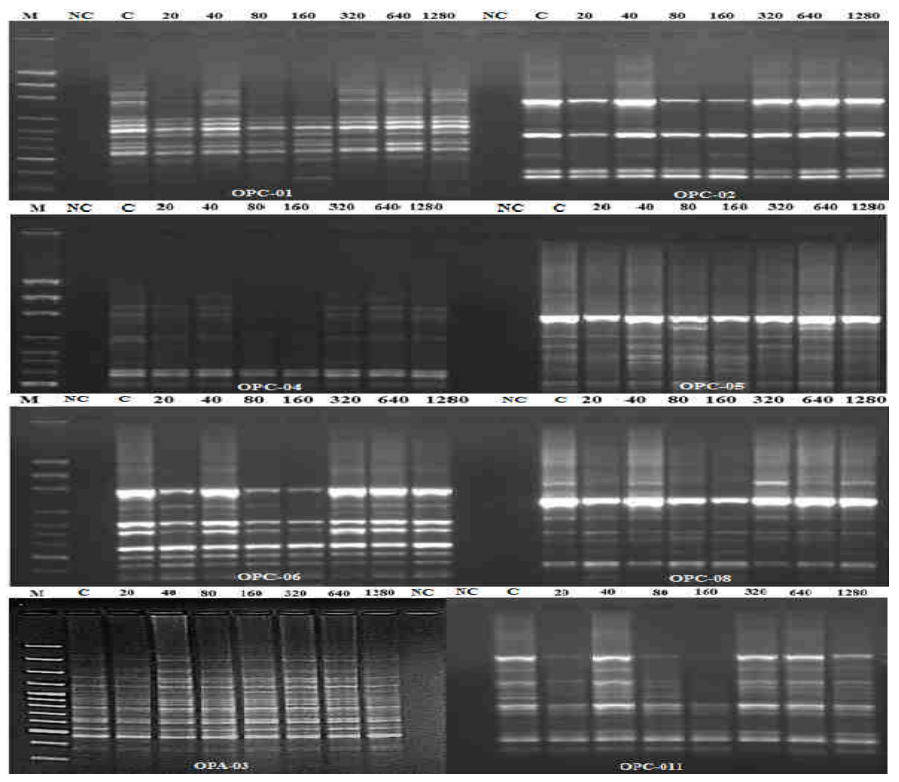

\section{M: Marker, NC: Negative Control, C: Control}

Fig.1: Agarose gel images of 8 primers that showed monomorphic band profiles in RAPD-PCR

\section{Analysis of data CRED-RA}

The digestion wasperformed with HpaII and MspI enzymes separately. Table 3 was used as a reference to evaluate the data gathered by the CRED-RA analysis.Restriction enzymes of HpaII and MspI have different digestion abilities based on the statute of cytosine in the methylation pattern. All the amplified bands obtained from the CRED-RA analysis were divided into four methylation types based on the presence or absence of groups as indicated by Li et al. (2005), Wang et al. (2011), Pan et al. (2011) and Karan et al. (2012) [2023]. According to these, methylation band profile was scored as the presence (1) or absence (0).

Table.3: Methylation types of HpaII and MspI restriction enzymes according to their digestion abilities

\begin{tabular}{|c|c|c|c|c|c|c|c|}
\hline \multirow[t]{2}{*}{ Туре } & \multirow{2}{*}{$\begin{array}{c}\text { Methylation } \\
\text { Patterns }\end{array}$} & \multirow[t]{2}{*}{ HpaII } & \multirow[t]{2}{*}{ MspI } & \multicolumn{3}{|c|}{$\begin{array}{c}\text { Score of Band } \\
\text { Profile }\end{array}$} & \\
\hline & & & & $\mathbf{x}$ & $\mathbf{y}$ & $\mathbf{z}$ & \\
\hline Type I & CCGG & digestion & digestion & $-/ 1$ & $+/ 0$ & $+/ 0$ & Non-methylation \\
\hline
\end{tabular}




\begin{tabular}{|l|c|c|c|c|c|c|c|c|}
\hline & \multicolumn{2}{|c|}{ GGCC } & & & & & \\
\hline \multirow{2}{*}{ Type II } & $\underline{\text { CCGG }}$ & $\underline{\mathbf{C} C G G}$ & digestion & undigestion & $-/ 1$ & $+/ 0$ & $-/ 1$ & Semi-methylation \\
\hline Type III & $\begin{array}{l}\text { GGCC } \\
\text { GG } \underline{\mathbf{C} C}\end{array}$ & undigestion & digestion & $-/ 1$ & $-/ 1$ & $+/ 0$ & Full-methylation \\
\hline Type IV & $\underline{\mathbf{C C G G}}$ & undigestion & undigestion & $-/ 1$ & $-/ 1$ & $-/ 1$ & Full-methylation \\
\hline
\end{tabular}

$\mathrm{x}$ : PCR product is not digested by by either enzyme

$\mathrm{y}$ : PCR product is digested by the HpaII enzyme undigestion

$\mathrm{z}$ : PCR product is digested by the MspI enzyme absence

\section{RAPD data analysis}

\section{RESULTS AND DISCUSSION}

According to previous studies, the reason of observing different bands in the RAPD profile is the mutations that happen on the places where the primers are bonded on DNA structure [20, 24-28]. In this study, according to the results of RAPD analysis, very important polymorphism was observed in sunflower samples with zinc stress. 14 of 20 RAPD primers were used in this study revealed polymorphic bands that were different from the control group of sunflower plants. In all the primers, OPC09 (57.20\%), OPC08 (55.50\%), OPC07 (50.00\%) and OPC11 (50.00\%) primers showed considerable polymorphic band patterns (Table 4). This result showed that these primers were powerful indicator for mutagenic effect of heavy metal of zinc for sunflower plants.According to the GTS rates adapted with RAPD profiles, the highest rate was $92.85 \%$ at $20 \mathrm{ppm}$ zinc concentration. The lowest rate was $83.33 \%$ at $640 \mathrm{ppm}$ zinc stress (Table 5). This clearly underlines the importance of the different concentration of zinc stress.

\begin{tabular}{ll} 
Table.4: Polymorphism rates for all primers \\
\hline Primers & Polymorphism rate(\%) \\
\hline OPA03 & 10,0 \\
OPA08 & 37,5 \\
OPB07 & 26,3 \\
OPC01 & 15,4 \\
OPC02 & 12,5 \\
OPC04 & 33,3 \\
OPC05 & 22,2 \\
OPC06 & 36,4 \\
OPC07 & 50,0 \\
\hline OPC08 & 55,5 \\
OPC09 & 57,2 \\
\hline OPC10 & 33,3 \\
\hline OPC11 & 50,0 \\
\hline OPF05 & 25,3 \\
\hline
\end{tabular}

“+" refer to digestion and "-" refer to

“ 1 " refer to band presence and " 0 " refer to band

Table 5. \% change of GTS rates

\begin{tabular}{cc}
\hline Samples & GTS rate $(\%)$ \\
\hline $20 \mathrm{ppm}$ & 92,85 \\
$40 \mathrm{ppm}$ & 91,66 \\
$80 \mathrm{ppm}$ & 90,47 \\
$160 \mathrm{ppm}$ & 88,09 \\
$320 \mathrm{ppm}$ & 85,71 \\
$640 \mathrm{ppm}$ & 83,33 \\
$1280 \mathrm{ppm}$ & 83,92 \\
\hline
\end{tabular}

\section{CRED-RA analysis}

Methylation of DNA is a chemical alteration in DNA's structure and plays an important role to regulate gene expression and genome defense in plants [29, 30]. Rassoulzadegan et al. (2006) determined the stress conditions such as heavy metal, salt and cold stress have caused changes in DNA methylation patterns [10]. Choi and Sano (2007) studied the effect of heavy metal of aluminum stress on tobacco plants and reported the aluminum stress led to changes on DNA methylation levels [31].In this study, the effects of zinc stress for different concentrations on sunflower plants were evaluated in terms of genetic and epigenetic parameters. It was observed that in sunflower plants used in CRED-RA analysis, the methylation types took different values in different concentrations. It was seen that there were some effects of heavy metals on DNA's methylation levels in epigenetic mechanisms and sunflower plants showed resistance to zinc heavy metal in different types of methylation.In order to observe the methylation models in genome of sunflower samples exposed to zinc stress, 8 primerswere analyzed one by one and the evaluations were made by taking the primers into consideration.

The analysis of the RAPD band profiles showed that from the 14 primers used for RAPD analysis, 8 primers which were capable of giving clear bands and produced monomorphic band patterns were chosen for CRED-RA analysis. The sequences of 8 primers were given in Table 
2. To evaluate the data taken after CRED-RA analysis, Table 3 was used as a reference. For the evaluation, methylation band profiles were evaluated according to Table 3 and were scored as presence (1) or absence (0).
The methylation types analyzed after CRED-RA reports. The scores of methylation types were given in Table 6 and shown in Figure 2 comparatively.

Table.6: The average (\%) rates of methylation types based on data obtained from CRED-RA analysis

\begin{tabular}{|c|c|c|c|c|c|c|c|c|}
\hline & Control & 20 & 40 & 80 & 160 & 320 & 640 & 1280 \\
\hline Type-I (\%) & 2,10 & 2,40 & 2,40 & 2,50 & 5,70 & 3,60 & 3,50 & 2,80 \\
\hline Type-II (\%) & 2,50 & 2,50 & 2,80 & 5,25 & 2,10 & 1,90 & 0,80 & 0,00 \\
\hline Type-III (\%) & 8,95 & 9,20 & 4,50 & 7,20 & 3,10 & 5,40 & 6,70 & 8,90 \\
\hline Type-IV (\%) & 86,45 & 85,90 & 90,30 & 85,05 & 89,10 & 89,10 & 89,00 & 88,30 \\
\hline Total methylated bands ratio $(\%)^{\mathrm{a}}$ & 97,90 & 97,60 & 97,60 & 97,50 & 94,30 & 96,40 & 96,50 & 97,20 \\
\hline Full-methylated bands ratio $(\%)^{b}$ & 95,40 & 95,10 & 94,80 & 92,20 & 92,20 & 94,50 & 95,70 & 97,20 \\
\hline Semi-methylated bands ratio $(\%)^{\mathrm{c}}$ & 2,50 & 2,50 & 2,80 & 5,25 & 2,10 & 1,90 & 0,80 & 0,00 \\
\hline
\end{tabular}

${ }^{a}$ Total methylated bands ratio $(\%)=[(\mathrm{II}+\mathrm{III}+\mathrm{IV}) /(\mathrm{I}+\mathrm{II}+\mathrm{III}+\mathrm{IV})] \times 100$

${ }^{\mathrm{b}}$ Full-methylated bands ratio $(\%)=[(\mathrm{III}+\mathrm{IV}) /(\mathrm{I}+\mathrm{II}+\mathrm{III}+\mathrm{IV})] \times 100$

${ }^{\mathrm{c}}$ Semi-methylated bands ratio $(\%)=[(\mathrm{II}) /(\mathrm{I}+\mathrm{II}+\mathrm{III}+\mathrm{IV})] \times 100$

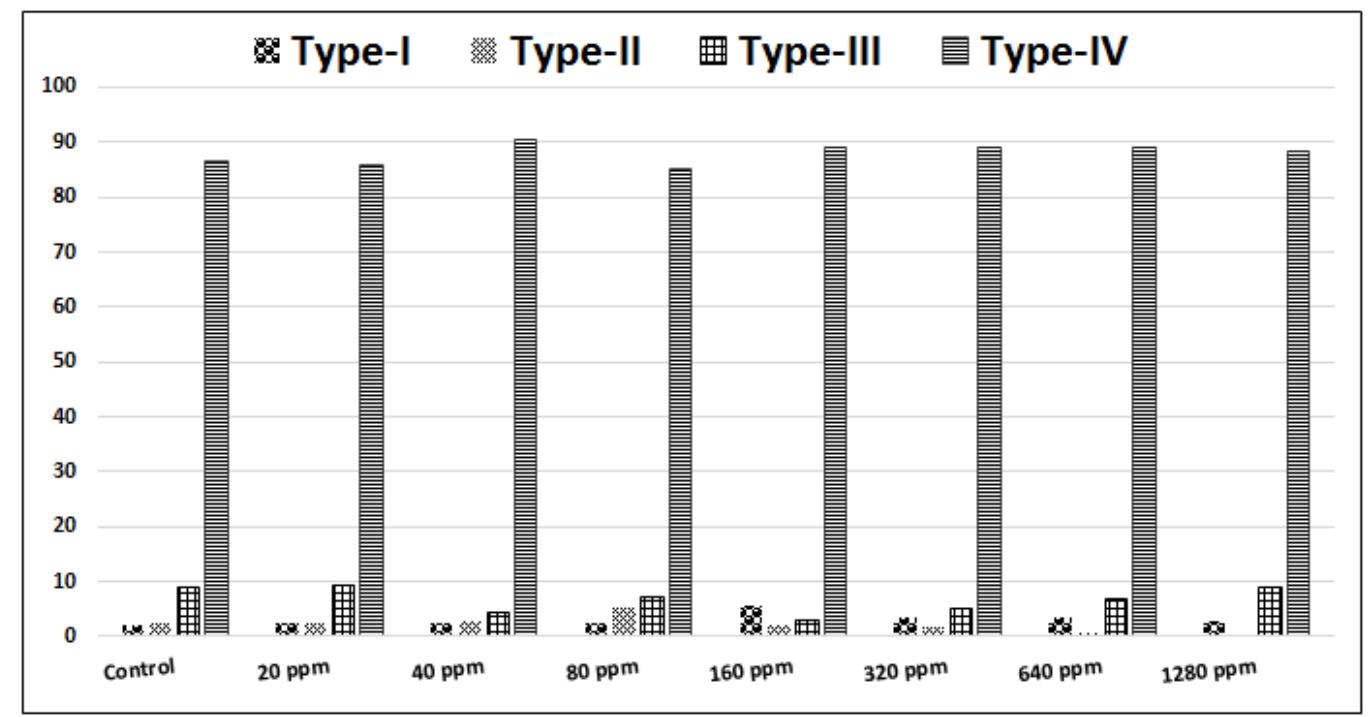

Fig.2: The average (\%) rates of methylation types obtained from CRED-RA analysis in sunflower samples.

According to the Karan et al. (2012) and Li et al. (2009) the percent ratio of total methylation, full-methylation and semi-methylation were calculated by using of the all methylation types. The formulas used in the calculation were given in Table 6, respectively.

When the average rates of methylation types were observed, Type I methylation's highest rate was 5.70 at 160ppm. Type I methylation represent non-methylation patterns. It means that methylatedcytosine is not on double strands of DNA or inner methylated cytosine on a single strand. It wasaccepted as non-methylatedcytosine according to the previous studies [22, 23]. According to this, non-methylation seemed to be present in all concentrations of zinc stress.

The highest rate of Type II methylation was $5.25 \%$ at $80 \mathrm{ppm}$ and non-existent at 1280ppm. Type II methylation represent semi-methylation pattern which is outer methylated of cytosine on a single DNA strand.Similarly, according to the previous studies, full-methylation signified that inner methylated cytosine (Type III) and outer methylated cytosine (Type IV) on DNA double strands.The highest rate of Type III methylation was $9.20 \%$ at $20 \mathrm{ppm}$ and the lowest level was seen $3.10 \%$ at $160 \mathrm{ppm}$. Type IV methylation was determined in highest grades for all zinc concentrations in all methylation types. The highest level was $90.30 \%$ at $40 \mathrm{ppm}$ and the lowest level was $85.05 \%$ at $80 \mathrm{ppm}$. In addition, full-methylation i.e. type III and type IV methylation completely appeared at all concentration of zinc stress.Also, the significant correlation was observed between the total methylation pattern and non-methylation pattern in sunflower seedlings subjected to zinc stress. The $\mathrm{R}^{2}$ value was 0.9381 (Figure 3). 


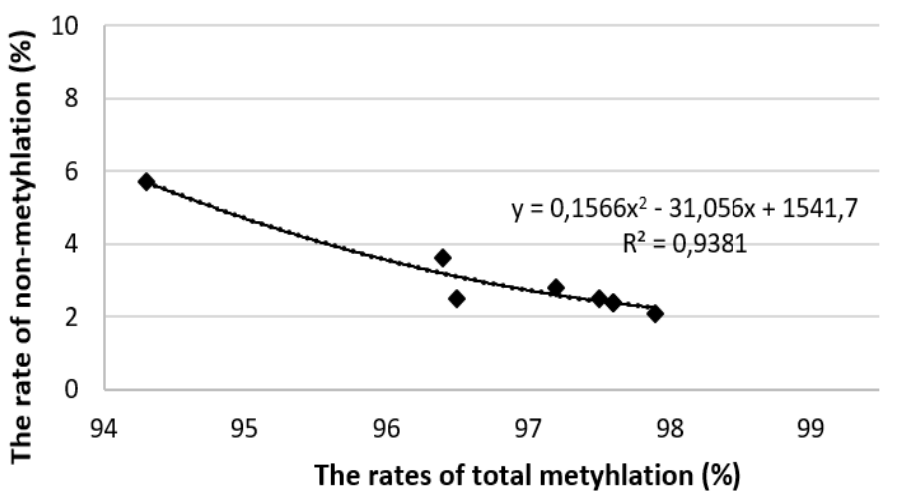

Fig.3: Influence of total methylation pattern to non-
Total methylation and full-methylation rates decreased until 160ppm zinc stress and then started to increase at $320 \mathrm{ppm}$ and following the increase of concentrations of zinc stress. This concentration (160 ppm)was observed the critical point for methylation activity. Results of CRED-RA analysis showed that there were differences in the genomic DNA methylation between the control group and treatments of zinc stress. The results of total, full, semi and non-methylation pattern levels were given in Figure 4, comparatively.

methylation pattern

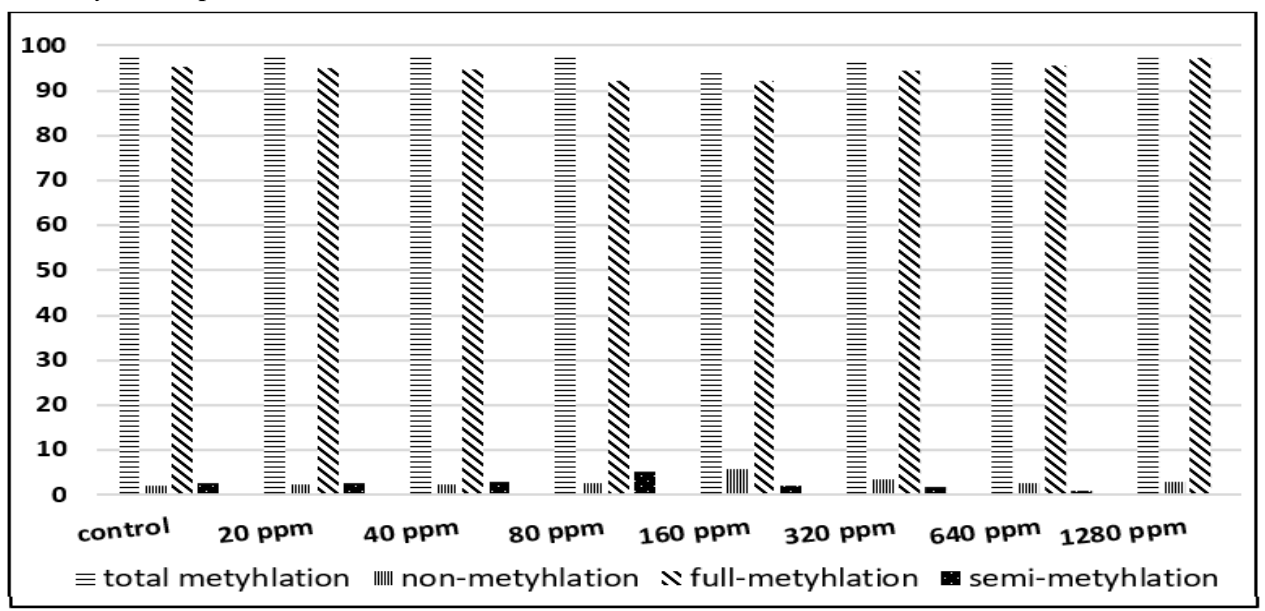

Fig.4: The (\%) ratio of methylation pattern types obtained from CRED-RA analysis in sunflower samples.

In conclusion, DNA methylation polymorphisms in response to abiotic stress conditions, heavy metal of zinc were analyzed different concentrations intervals by the technique of CRED-RA in sunflower plants. Highly important polymorphisms and methylation changes were observed. Changes in the level of methylation patterns were seen to be effective on bio-defense mechanism in sunflower plants. Also, the results of this study give information about zinc is a genotoxic agent for sunflower plants and it can be useful for restoring heavy metals contaminated areas.

\section{REFERENCES}

[1] Koc, E., Ustun, A.S. and Arici, Y. 2012. Effect of Different Zinc Concentrations on Total Protein, Hydrogen Peroxide Content and Peroxidase Activity in Pepper (Capsicum annuum L.) Seedlings. Artvin Coruh University, Journal of Forestry Faculty, 13(2), 205-212.

[2] Kirbag, F. and Munzuroglu, O. 2006. Toxic effects of cadmium $\left(\mathrm{Cd}^{++}\right)$on metabolism of sunflower (Helianthus annuus L.) seedlings. Acta Agric Scand, Section B - Soil and Plant Sci (3); 56, 224229.
[3] Burzynski, M. and Klobus, G. 2004. Changes of photosynthetic parameters in cucumber leaves under $\mathrm{Cu}, \mathrm{Cd}$ and $\mathrm{Pb}$ stress. Photosynth 42(4), 505-510.

[4] Assche, V., Clijters, H., 1990. Effect of metal on enzyme activity on plants, Plant Cell Environ. 13, 195-206.

[5] Conte, C., Mutti, I., Puglisi, P., Ferrarini, A., Regina, G.R.G., Maestri, E., Marmiroli, N., 1998. DNA fingerprint analysis by PCR based method for monitoring the genotoxic effects of heavy metals pollution. Chemosphere 37, 2739-2749.

[6] Savva, D. 1998. Use of the DNA fingerprinting to detect genotoxic effects. Ecotoxicol. Environ. Safely, 41, 103-106.

[7] Hall, J.L. 2002. Cellular mechanisms for heavy metal detoxification and tolerance. Journal of Experimental Botany, 53, 1-11.

[8] Khurana, N. and Chatterjee, C. 2001. Influence of variable zinc on yield, oil content, and physiology of sunflower. Commun Soil Sci. Plant Anal., 32, 3023-3030.

[9] Bobak, M. 1985. Ultrastructure changes of the nucleus and its components in meristematic root 
cells of the horse-bean after zinc in toxication. Physiol Plants, 15, 31-36.

[10] Rassoulzadegan, M., Grandjean, V., Gounon, P., Vincent, S., Gillot, I., Cuzin, F. 2006. RNAmediated non-mendelian inheritance of an epigenetic change in the mouse, Nature, 441; 469474.

[11] Mirouze, M. and Paszkowski, J. 2011. Epigenetic contribution to stress adaptation in plants, Current opinion in plant biology, 14;267-274.

[12] Chinnusamy, V. and Zhu, J.K. 2009. Epigenetic regulation of stress responses in plants, Current opinion in plant biology, 12; 133-139.

[13] Suzuki, M.M. and Bird, A. 2008. DNA methylation landscapes: provocative insights from epigenomics, Nature Reviews Genetics, 9; 465476.

[14] Grigg, G. and Clark, S. 1994. Genes and genomes: Sequencing 5-methylcytosine residues in genomic DNA, Bioessays, 16; 431-436.

[15] Rein, T., DePamphilis, M.L. and Zorbas, H. 1998. Identifying 5-methylcytosine and related modifications in DNA genomes, Nucleic acids research, 26; 2255-2264.

[16] Cai, Q., Guy, C.L. and Moore G.A. 1996. Detection of cytosine methylation and mapping of a gene influencing cytosine methylation in the genome of Citrus, Genome, 39; 235-242.

[17] Leljak-Levanic, D., Bauer, N., Mihaljevic, S., Jelaska, S. 2004. Changes in DNA methylation during somatic embryogenesis in Cucurbita pepo L, Plant cell reports, 23; 120-127.

[18] Tani, E., Polidoros, A., Nianiou-Obeidat, I., Tsaftaris, A. 2005. DNA methylation patterns are differently affected by planting density in maize inbreds and their hybrids, Maydica, 50, 19.

[19] Lefort, F., Lally, M., Thompson, D., Douglas, G. 1998. Morphological traits, microsatellite fingerprinting and genetic relatedness of a stand of elite oaks (Q. robur L.) at Tullynally, Ireland, Silvae Genetica, 47; 257-261.

[20] Liu, W., Li, P., Qi, X., Zhou, Q., Zheng, L., Sun, T., Yang,Y. 2005. DNA changes in barley Hordeum vulgare seedlings induced by cadmium pollution using RAPD analysis, Chemosphere, 61; 158-167.

[21] Wang, W.S., Pan, Y.J., Zhao, X.Q., Dwivedi, D., Zhu, L.H., Ali, J., Fu, B.Y., Li, Z.K. 2011. Drought-induced site-specific DNA methylation and its association with drought tolerance in rice (Oryza sativa L.), Journal of experimental botany, 62; 1951-1960.
[22] Karan, R., DeLeon, T., Biradar, H., Subudhi, P.K. 2012. Salt stress induced variation in DNA methylation pattern and its influence on gene expression in contrasting rice genotypes, PloS one, 7; e40203.

[23] Pan, Y., Wang, W., Zhao, X., Zhu, L., Fu, B., Li, Z. 2011. DNA methylation alterations of rice in response to cold stress, Plant Omics J, 4; 364-369.

[24] Savva, D. 2000. The use of arbitrarily primed PCR (AP-PCR) fingerprinting to detect exposure to genotoxic chemicals. Ecotoxicology, 9; 341-353.

[25] Theodorakis, C.W., Bickham, J.W. and Lamb, T. 2001. Integration of genotoxicity and population genetic analyses in kangaroo rats (Dipodomys merriami) exposed to radionuclide contamination at the Nevada test site, USA. Environmental Toxicology and Chemistry, 20; 317-326.

[26] Atienzar, F.A., Venier, P., Jha, A.N. and Depledge, M.H. 2002. Evaluation of the random amplified polymorphic DNA (RAPD) assay for the detection of DNA damage and mutations. Mutation Research, 521; 151-163.

[27] Liu, W., Yang, Y.S., Zhou, Q. X., Xie, L.J., Li, P.J. and Sun, T.H. 2007. Impact assessment of cadmium contamination on rice (Oryza sativa L.) seedlings at molecular and population levels using multiple biomarkers. Chemosphere, 67; 11551163.

[28] Liu, W., Yang, Y.S., Li, P.J., Zhou, Q.X., Xie, L.J. and Han, Y.P. 2009. Risk assessment of cadmiumcontaminated soil on plant DNA damage using RAPD and physiological indices. Journal of Hazardous Material. 161; 878-883.

[29] Jaenisch, R. and Bird, A. 2003. Epigenetic regulation of gene expression: how the genome integrates intrinsic and environmental signals. Nature Genetics, 33, 245.

[30] Richards, E,J. 1997. DNA methylation and plant development. Trends Genet, 13: 319-323.

[31] Choi, C.S. and Sano, H. 2007. Abiotic-stress induces demethylation and transcriptional activation of a gene encoding a glycerophosphodiesterase-like protein in tobacco plants, Molecular Genetics and Genomics, 277; 589-600. 